\title{
Debt Overhang and Output Stimulation in Nigeria
}

\author{
Okwaraji, E. C $\mathrm{C}^{1}$., \& Ifionu E. P2. \\ ${ }^{1}$ Department of Finance and Banking, University of Port Harcourt, Nigeria \\ ${ }^{2}$ Associate Professor, Department of Finance and Banking, University of Port Harcourt, Nigeria \\ Corresponding Author (Email: ebele.ifionu@uniport.edu.ng )
}

\section{ABSTRACT}

This study examines the association between debt overhang and output stimulation in Nigeria for a period of 37 years extending from 1981 to 2017, utilizing time series data sourced from the statistical bulletin of Central Bank of Nigeria. Public domestic bank debit outstanding, public domestic non-bank debt outstanding, public foreign multilateral debt outstanding, and public foreign informal debt outstanding was employed as indices of debt overhang, with real gross domestic product utilized as proxy of output stimulation. The study employed ex-post facto research design. The augmented Dickey-Fuller unit root test carried out revealed that all the variables are integrated of order one. The Johansen cointegration test carried out divulged the presence of long run relationship among employed variables. From the result of the study public domestic bank debt outstanding, public domestic non-bank debt outstanding, and public foreign multilateral debt outstanding have positive and significant impact on real gross domestic product, while public foreign informal debt outstanding exerts a positive and insignificant impact on real gross domestic product. The study recommended that the Federal government should sustain current level of debt or decrease the level of debt and also ensure that fund sourced from external and domestic sources are channelled to the designated projects.

Keywords: Real Gross Domestic Output in Nigeria, Public Domestic Bank Debt outstanding, Public Domestic Non-Bank Debt outstanding, Public Foreign Multilateral Debt outstanding and Public Foreign Informal Debt outstanding.

DOI: $10.7176 / \mathrm{EJBM} / 12-10-06$

Publication date: April $30^{\text {th }} 2020$

\subsection{Introduction}

The justification for government borrowing has its foundation in the neoclassical growth models, which prescribes the need for capital scarce countries to borrow in order to increase their capital accumulation and steady state level of output per capita (Omotosho, Bawa, \& Doguwa, 2016). According to Cecchetti et al. (2011), debt is a two-edged sword. In other words, it is capable of improving welfare when used wisely and in moderation, but can also be disastrous when used recklessly. This assertion suggests that borrowing is only appropriate under certain circumstances and government needs to exercise caution while crafting their debt policies. However, it has also been argued that the accumulation of debt beyond certain limits could offset the positive impacts of public borrowing based on the overhang effect (Ritschl \& Sarferaz, 2014).

Debt overhang can be fundamentally described as "the condition of an organization, business, government, or institution that has existing debt so great that it cannot easily borrow more money, even when that new borrowing is actually a good investment that would more than pay for itself'. On another hand, it can be defined as a debt burden that is so large that an entity cannot take on additional debt to finance future projects, even those that are profitable enough to enable it to reduce its indebtedness over time. Debt overhang serves to dissuade current investment, since all earnings from new projects would only go to existing debt holders, leaving little incentive for the entity to attempt to dig itself out of the hole. In the context of sovereign governments, the term refers to a situation where the debt stock of a nation exceeds its future capacity to repay it (Boboye \& Ojo, 2012).

Since some Economic theory suggests that reasonable levels of borrowing by a developing country are likely to enhance its economic growth, debt thus become paramount (Egbetunde, 2012), According to Udoka and Ogege (2012), Debt, therefore, refers to the resources of money in use in an organization which is not contributed by its owners and does not in any other way belong to them. It is a liability represented by a financial instrument of other formal equivalent. When a government borrows, the debts is a public debt, Debts are incurred by government through borrowing in the domestic and international markets to finance domestic investment. Therefore, the national debt is seen as all claims against the government held by the private sector of the economy, or by foreigners, whether interest-bearing or not (and including bank held debt and government currency, if any); less any claims held by the government against the private sector and foreigners (Adamu and Rasiah, 2016). 
Woodrow Wilson overtime emphasized that in identifying and understanding key elements, there is a need to understand the subtle and unformulated conditions. In this light, Achieving National growth has been a paramount goal pursued by most countries, a key phenomenon to economic growth as explained by Ezebasily and Nwakoby (2013) is the pivotal role of the Public sector in initiating, managing and financing this proposed growth and development, Adesuyi and Falowo (2013) expatiated on the fact that Nigeria is a less developed nation largely characterized by its low per capita income, and despite its shift from its agricultural based after the discovery of oil, it fiscal policy has lacked the intended goal of efficient macroeconomic management, Adeoye (2006) in this light added that this has resulted in an elastic expenditure by the government which has induced a Debt in the nation that is still on the rise.

However, over time there has been a strong debate as to the efficacy of debt overhang as an instrument of growth, this debate is more intense when the long run association is considered (Umaru \& Gatawa, 2014). As Fasoranti and Amasoma (2013); Umaru and Gatawa (2014); Ojong and Owui (2013), Edame and Okoi (2015) identifies that overbearing debt has a significant growth effect based on the argument grounded by the crowding out theorem which emphasizes that increases in government expenditure generally leads to an inefficient allocation of society's resources by starving more efficient private investors of investment funds. In essence, government spending essentially "crowds out private investment while other schools of thought grounded on the Ricardian Theory such as Mohanty (2012) sees Debt overhang and intensive deficit measures as not having any growth effects based on the argument of its inability to stimulate consumption or crowd Out Private Investment.

\section{Literature Review}

\subsection{Conceptual/Theoretical Foundations}

According to Udoka (2012), Nigeria's external indebtedness dates back to pre-independence period. However, the quantum of the debt was small until 1978. The debts incurred before 1978 were mainly long-term loans from multilateral and official sources such as the World Bank and the country's major trading partners. The debts were not much of a burden on the economy because the loans were obtained on soft terms. Moreover, the country had abundant revenue receipts from oil, especially during the oil boom of 1973-1976.

The total external debt outstanding as at 31 st December 2004 stood at US\$35.94 billion as against US\$32.92 billion in December 2003, indicating an increase of US\$3.03 billion or 9.20 percent. As was the case in the year 2003, the increase in the debt stock was largely as a result of the interest component of additional payment arrears that accumulated, and continued depreciation of the US dollar against other currencies in which the debts were denominated.

The additional interest of US\$1.54 billion was made up of contractual interest of US\$1.30 billion and late/penalty interest of US $\$ 0.233$ billion, but the increase due to the effect of the depreciation of the US dollar was approximately US\$1.49 billion.

A further breakdown of the total debt outstanding showed that the principal balance was US $\$ 30.29$ billion; principal arrears amounted to US\$1.94 billion, interest arrears and late interest were US\$3.36 billion and US $\$ 0.357$ billion respectively. The increase in the external debt stock was due primarily to arrears that were incurred as a result of non-servicing of the non-ODA (non-official development assistance) bilateral debt: arrears on this debt accounted for 96.6 percent of total arrears.

Theoretically, two baseline theories are appropriately reviewed for this study. They are Ricardian School activity theory and Profligacy Theory.

Barro (1989) known as the Ricardian Equivalence Hypothesis (REH). Ricardian equivalence, or the BarroRicardo equivalence proposition, is an economic theory which suggests that government budget deficits do not affect the total level of demand in an economy. In simple terms, the theory can be described as follows. Governments may either finance their spending by taxing current taxpayers, or they may borrow money. However, they must eventually repay this borrowing by raising taxes above what they would otherwise have been in future. The choice is therefore between "tax now" and "tax later". Suppose that the government finances some extra spending through deficits - i.e. tax later, Ricardo argued that although taxpayers would have more money now, they would realize that they would have to pay higher tax in future and therefore save the extra money in order to pay the future tax.

Krugman (1988) stated that profligacy thesis attempts to correct the weakness of growth - cum debt theory by focusing on the institutional arrangement under which a loan was contracted. The profligacy thesis, a component of the system stability theory, recognizes that the debt crisis arose from weak institutions and policies that have 
wasted resources through unbridled official corruption and damaged living standards and development. These policies led to distortions in relative prices and encouraged capital flights - as seen in substantial external liquid funds of private citizens of debtor countries in foreign banks. (Nyong, 2005)

In summary, many factors are identified as responsible for the dissonance between debt and growth in low income countries. These include (1) adverse terms of trade (ii) waste of resources due to policy deficiencies, poor governance, and weak institutions in public sector dominated economies (iii) inadequate debt management reflected in unrestrained borrowing at unfavorable terms. (iv) non-concessional lending and in financing policies motivated in part by the desire of lenders to promote their own exports (Stephens, 1999) (v) political factors such as social strive or tension with devastating economic consequences Nyong, 2005).

\subsection{Empirical evidence}

Malik, Hayat, \& Hayat (2010) explored the relationship between external debt overhang and economic growth in Pakistan for the period between 1972 - 2005, using time series econometric technique. Their result shows that external debt is negatively and significantly related to economic growth. The evidence suggests that increase in external debt will lead to decline in economic growth.

Ogege and Ekpudu (2010) examined the impact of debt burden on the Nigerian economy using time series data from 1970-2007. Ordinary least square (OLS) was used to test the relationship between debt burden and growth of the Nigeria economy. The result showed a negative relationship between debt stocks of internal and external; and gross domestic product, meaning that an increase in debt stock will lead to a reduction on the growth rate of Nigerian economy.

Momodu (2012) examined the correlation between debt overhang and economic growth in Nigeria. The study sought to find a relationship between the Gross Domestic product (GDP) and Gross Fixed Capital Formation of Current Market Prices (GFCF) using Ordinary Least Square multiple regression method. The study revealed that debt payment to Nigerian creditors has significantly impacted on the GDP and GFCF.

Kasidi\& Said (2013) investigated the impact of external debt overhang and economic of growth in Tanzania using time series of' 1990-2010. The study revealed that there is significant impact of the external debt and debt service on GDP growth. Whereas total external debt stock has a positive effect of about 036939, debt service payment has a negative effect of about 28.517 .

Mbah and Umunna (2015) also studied the effect of Nigeria external debt profile on unemployment and poverty rate and low standard of living using the ARDL bound testing approach to co integration, error correction models and the Granger causality test for the periods $1970-2014$. The finding established a unidirectional causality between external debt and unemployment and poverty rate. Consequently, the study recommends, government should imbibe the habit of savings and formulate policies that will attract foreign exchange that could help in financing developmental projects instead of resolving to borrowing.

Sulaiman \& Azeez (2012), examined the effect of external debt overhang on the economic growth of Nigeria. Annual time series data was gathered from the Central Bank Nigeria Statistical bulletin and Debt Management Office from 1970 to 2010. The econometric techniques of Ordinary Least Square (OLS), Augmented DickeyFuller (ADF) Unit Root test, Johansen Co-integration test and Error Correction Method (ECM) are employed in the empirical analysis. The co-integration test shows that long-run equilibrium relationship exist among the variables. The findings from the error correction method show that external debt has contributed positively to the Nigerian economy. The study recommends that government should ensure economic and political stability and external debt largely for economic reasons rather than social or political reasons.

Paiko (2012) examines the impact of government expenditures on private investment and also how the financing of debt overhang has not only affected the performance of private investment but also how it crowds out private investment in Nigeria over the time period of 1990 to 2007. Secondary data from CBN statistical bulletin Bureau of statistics bulletin were used Econometric models were used in calculating the relative impact of deficit financing on private investment in Nigeria. The findings revealed a negative relationship between deficit financing and investment in the period under review

Osuka and Chioma (2014) evaluated the impact of debt overhang on macro-economic variables in the Nigerian economy for the period 1981-2012. Their study utilized the Augmented Dickey-Fuller (ADF) methods and Johansen Cointegration test to check for the cointegration of the variables and found that the variables in the 
study are all cointegrated of order one showing the presence of long-run relationship between employed variables (GDP, interest rate, nominal exchange rate and inflation rate). However, the test for causality showed that there exists no causality between deficits and interest rate, budget deficits and inflation and budget deficit and nominal exchange rate. We thereby concluded that budget deficits exert significant impact on the macroeconomic performance of the Nigerian economy.

Onuorah and Nkwazema (2014) examined the effect of Debt overhang on the economy. The study utilized data from publications of the Central Bank of Nigeria Statistical Bulletin between 1981- 2012. The paper applied descriptive statistics, OLS, Diagnostic test, ADF unit root, Johansen Co-integration and pairwise Granger causality test and their findings showed that the variables were stationary at first difference data 1(1). The variables were jointly co-integrated at 5\% level. Showing that Debt overhang was seen to be statistically significant and positively related to Output Stimulation in Nigeria.

Bamidele \& Joseph (2013) examined the effect of financial crisis, external debt management on the economic growth of Nigeria using GDP as endogenous variable while exogenous variables measuring economic growth were Foreign Direct investment, external debt, external reserve, inflating, and exchange rate proxies. Annual time series of 1980-20 10 were used. OLS, Augmented Dickey Fuller (ADF) unit roof tests and the Granger causality test were employed in analysis. The result showed a positive relationship between FDI and economic growth while inverse relationship existed between external debt and economic growth.

Sichula (2012) investigated debt overhang in five Heavily Indebted Poor Countries (HIPC) of the Southern African Development Community (SADC), utilizing data for the period 1970 to 2011. The study showed a significant relationship between external debt and GDP. As external debt decreases, GDP increases. As those countries attain HIPC completion point, they witnessed increases in their real GDP occasioned by declines in debt service payments.

Wright and Grenade (2014) indicated a non-linear relationship between debt and growth in a panel OLS and threshold dynamics in 13 Caribbean countries. The study found a debt/GDP ratio of 61 per cent for the sample countries, with a debt/GDP ratio exceeding that threshold having an adverse impact on investment and growth. The results showed marked divergence between actual debt/GDP ratios and the calibrated optimal ratios at the country levels. The study indicated that the negative debt-growth relationship reinforced the point that government borrowing must be done not only on terms that are consistent with entrenching debt sustainability, but also on terms that yields growth dividends in the long run.

\section{Methodology}

This section presents the data used, as shown in Table 1, Appendix 1. It is time series secondary data sourced from Central Bank of Nigeria (CBN) Statistical Bulletin. The period covered spans from 1981 to 2017. This section also provides for econometric tools employed. Some of them are as explained below.

\section{Unit Root Test}

The empirical section primarily examines the stationary conditions of the data applying the augmented Dickey Fuller (1979) test and the Phillips-Perron (1988) test. Dickey and Fuller stretched the procedure of their test proposing an augmented version that contained more lagged term of endogenous variable to eradicate the autocorrelation.

\section{Co-integration}

Co-integration test is applied to find out the long run relationship between the used variables. This technique is used when two variables are non-stationary but their linear combination demonstrates lower order of integration.

\section{Parsimonious Dynamic Error Correction Model}

This seeks to correct the error in the model. Error Correction Models (ECMs) entails a series of longitudinal models which seeks to appraise the amendment speed at which a criterion variable returns to equilibrium after a change in a Predictor variable.

Estimation of ECMs of the form:

$$
\text { et } 1+v t \square
$$

(Mannina et al. 2010)

ECMs are useful for appraising the long- and short-term influences of one longitudinal on another. This research will utilize vector Error correction model. 
Model specification

This study formulates its model in a functional and mathematical forms respectively as

$\mathrm{RGDP}_{\mathrm{t}}=f\left(\mathrm{PBND}_{\mathrm{t}}, \mathrm{PNND}_{\mathrm{t}}, \mathrm{PFMD}_{\mathrm{t}}, \mathrm{PFBD}_{\mathrm{t}}\right)$

$\mathrm{RGDP}_{\mathrm{t}}=\alpha_{0}+\alpha_{1} \mathrm{PBND}_{\mathrm{t}}+\alpha_{2} \mathrm{PNND}_{\mathrm{t}}+\alpha_{3} \mathrm{PFMD}_{\mathrm{t}}+\alpha_{4} \mathrm{PFBD}_{\mathrm{t}}+\mu$

Econometrically, the model is presented as follows

LnRGDP $=\alpha_{0}+\alpha_{1}$ LnPBND $+\alpha_{2}$ LnPNND $+\alpha_{3}$ LnPFMD $+\alpha_{4}$ LnPFBD $+\mu(3)$

Where:

RGDP $=\quad$ Real Gross Domestic Output

PBND = Public Domestic Bank Debt outstanding

PNND $=\quad$ Public Domestic Non-Bank Debt outstanding

PFMD $=\quad$ Public Foreign Multilateral Debt outstanding

PFBD $=\quad$ Public Foreign Informal Debt outstanding

$\alpha_{0} \quad=\quad$ Constant Term

$\alpha_{1}-\alpha_{4}=$ Coefficients of variables

Ln $\quad=\quad$ Natural Logarithm

Operational measure of variables

Real Gross Domestic Output:

This is the macroeconomic variable which is used as a measure of the value of the economic output fixed for price fluctuation. It is one of various ways to capture the level of Growth in an economy. It is measured in Billions of Naira.

Public Domestic Bank Debt outstanding $\left(\alpha_{1}\right)$ : This is the amount outstanding of the money raised by the Government, in local currency and from its banks, it is expected to exhibit a positive relationship to growth; as an increase in the Domestic debt level should increase the national output through production stimulation, this variable will be measured in Billions of Naira.

Public Domestic Non-Bank Debt outstanding $\left(\boldsymbol{\alpha}_{2}\right)$ : This is the amount outstanding of money raised by the Government, in local currency and from its residents and other, it is theoretically anticipated that an increase in this should increase the output level and growth in the economy, this variable will be measured in Billions of Naira.

Public Foreign Multilateral Debt outstanding $\left(\boldsymbol{\alpha}_{3}\right)$ : This is the amount outstanding of money raised by the Government, via international currency from multilateral corporations, an increase in this is expected to stimulate output growth in the nation and will be captured in billions of Naira.

Public Foreign Informal Debt outstanding $\left(\boldsymbol{\alpha}_{4}\right)$ : This is the amount outstanding of money raised by the Government, via international currency from a country or corporations in another country this is expected to have a positive relationship with Output Stimulation and will be measured in billions of Naira.

\section{Data Analysis and Presentation of Estimation Results}

Data for the study are analyzed accordingly and presented as estimation results.

\section{1: Presentation of Stationarity (Unit Root) Tests Result}

The unit root test is carried out using Augmented Dickey Fuller (ADF) test to evaluate the stationarity of the variables employed for the research. The result of the unit root test is presented in Table 2 below. 
Table 2. Result of Stationarity (Unit Root) Tests:

\begin{tabular}{|c|c|c|c|c|c|c|}
\hline \multirow[t]{2}{*}{ Variable } & \multirow{2}{*}{$\begin{array}{l}\text { ADF } \\
\text { statistic }\end{array}$} & \multicolumn{3}{|c|}{ Critical Value 5\% } & \multirow{2}{*}{$\begin{array}{l}\text { Order of } \\
\text { Integration }\end{array}$} & \multirow[b]{2}{*}{ Prob. } \\
\hline & & $1 \%$ & $5 \%$ & $10 \%$ & & \\
\hline RGDP & -6.583372 & -4.252879 & -3.548490 & -3.207094 & $\mathrm{I}(1)$ & 0.0000 \\
\hline PBND & -4.545883 & -4.273277 & -3.557759 & -3.212361 & $\mathrm{I}(1)$ & 0.0052 \\
\hline PNND & -3.608621 & -4.356068 & -3.595026 & -3.233456 & $\mathrm{I}(1)$ & 0.0000 \\
\hline PFMD & -5.842827 & -4.273277 & -3.557759 & -3.212361 & $\mathrm{I}(1)$ & 0.0100 \\
\hline PFBD & -3.708108 & -4.243644 & -3.544284 & -3.204699 & $\mathrm{I}(1)$ & 0.0350 \\
\hline
\end{tabular}

Using both 1\% and 5\% Substantial Level.

Source: Eview 9 Output (Authors' Computation and Compilation)

The table above documents the ADF Unit root test result, comparing the ADF test statistic value with the Critical values at $5 \%$ level of, all the variables are stationary after differencing once 1(1). This implies that all the variables are integrated of order one and have a stable trend which can be employed for estimation and future forecast.

\subsection{Presentation of Johansen Co-integration Test Results:}

Johansen approach of cointegration test was utilized and the outcome of the test presented below;

Table 3. Result of Johansen Unrestricted Co-integration Rank Test (Trace)

Date: 03/28/19 Time: 16:09

Sample (adjusted): 19832017

Included observations: 35 after adjustments

Trend assumption: Linear deterministic trend

Series: RGDP PBND PNND PFMD PFBD

Lags interval (in first differences): 1 to 1

Unrestricted Cointegration Rank Test (Trace)

\begin{tabular}{ccccc}
\hline \hline $\begin{array}{c}\text { Hypothesized } \\
\text { No. of CE(s) }\end{array}$ & Eigenvalue & $\begin{array}{c}\text { Trace } \\
\text { Statistic }\end{array}$ & $\begin{array}{c}0.05 \\
\text { Critical Value }\end{array}$ & Prob.** \\
\hline \hline None $*$ & 0.820540 & 133.2076 & 69.81889 & 0.0000 \\
At most $1 *$ & 0.556773 & 73.08444 & 47.85613 & 0.0000 \\
At most 2* & 0.451222 & 44.60584 & 29.79707 & 0.0005 \\
At most 3 & 0.381635 & 23.60369 & 15.49471 & 0.0024 \\
At most 4 & 0.176107 & 6.780031 & 3.841466 & 0.0092 \\
\hline \hline
\end{tabular}

Trace test indicates 5 cointegrating eqn(s) at the 0.05 level

$*$ denotes rejection of the hypothesis at the 0.05 level

**MacKinnon-Haug-Michelis (1999) p-values

As disclosed by the outcome of the Johansen cointegration test documented above, the trace test shows that there exist five (2) cointegrating equations with the Max-eigenvalue test revealing the presence of two (2) cointegrating equations. This suggests that there is a long run relationship between real gross domestic product, public domestic bank debt outstanding, public domestic non-bank debt outstanding, public foreign multilateral debt outstanding, and public foreign informal debt outstanding. Put differently. Variables (real gross domestic product, public domestic bank debt outstanding, public domestic non-bank debt outstanding, public foreign 
multilateral debt outstanding, and public foreign informal debt outstanding) move together in the long run. The confirmation of an existence of long run relationship between the variables gives credence to the conduct of the error correction mechanism.

\section{3: Presentation of Estimation Results}

\section{Error Correction Model (ECM)}

\section{Table 4: MODEL 1}

Dependent Variable: D(RGDP)

Method: Least Squares

Date: 03/28/19 Time: 16:22

Sample (adjusted): 19832017

Included observations: 35 after adjustments

\begin{tabular}{crccc}
\hline \hline Variable & Coefficient & Std. Error & t-Statistic & Prob. \\
\hline \hline D(PBND(-1)) & 2.418138 & 0.848640 & 2.849428 & 0.0080 \\
D(PNND(-1)) & 2.717358 & 1.057770 & 2.568949 & 0.0156 \\
D(PFMD(-1)) & 6.014039 & 2.375068 & 2.532155 & 0.0170 \\
D(PFBD(-1)) & 0.424301 & 0.394697 & 1.075004 & 0.2912 \\
ECM(-1) & -0.126131 & 0.057758 & -2.183780 & 0.0372 \\
C & 1130.124 & 263.2446 & 4.293058 & 0.0002 \\
\hline \hline R-squared & 0.892260 & Mean dependent var & 1528.740 \\
Adjusted R-squared & 0.787477 & S.D. dependent var & 1519.344 \\
S.E. of regression & 1282.495 & Akaike info criterion & 17.30581 \\
Sum squared resid & 47698980 & Schwarz criterion & 17.57244 \\
Log likelihood & -296.8516 & Hannan-Quinn criter. & 17.39785 \\
F-statistic & 3.743553 & Durbin-Watson stat & 1.891438 \\
Prob(F-statistic) & 0.009764 & & \\
\hline \hline
\end{tabular}

\section{Source: Own computation using Eviews 10}

The result of the error correction mechanism (ECM) test carried out and documented in the table above showed that the coefficient of determination is 0.892 . This suggests that, 89 percent variation in the dependent variable RGDP is accounted for by the independent variables (PBND, PNND, PFMD, PFBD), with the remainder of 11 percent accounted for by variables not incorporated in the model by captured by the error term. As observed in table 4.3, lag 1 of PBND has a significant positive impact on real gross domestic product, suggesting that it is a predictor of future changes in real gross domestic product. The short run behaviour of PNND showed that its lag 1 influences real gross domestic product positively and significantly. PFMD on the other hand, was found to exert a positive impact on real gross domestic product in the short run. Further observation showed that, PFBD like other variables of the model exert a positive impact on real domestic product but the uncovered relationship was found to be insignificant. The probability value of the F-statistics computed to be 0.009764 revealed that jointly the explanatory variables are significant in influencing short run variation or fluctuations in real domestic product and the model is correctly specified and statistical significant at 5 percent level. Further analysis of the result of table 4.3 revealed that, fluctuations in the RGDP that results from each of the independent or the totality of the regressors are corrected at the speed of 12 percent. Put differently, the speed of adjustment of the model is 12 percent. This means that temporal distortion in the model emanating from the independent variables will be adjusted and return to equilibrium in the long-run at the speed of $12 \%$.

\section{Summary, Conclusion and Recommendations}

\subsection{Summary}

As observed PBND has a significant positive impact on real gross domestic product, suggesting that it is a predictor of future changes in real gross domestic product. The short run behaviour of PNND showed that its lag 1 influences real gross domestic product positively and significantly. PFMD on the other hand, was found to exert a positive impact on real gross domestic product in the short run. Further observation showed that, PFBD 
like other variables of the model exert a positive impact on real domestic product but the uncovered relationship was found to be insignificant. The probability value of the F-statistics computed to be 0.009764 revealed that jointly the explanatory variables are significant in influencing short run variation or fluctuations in real domestic product and the model is correctly specified and statistical significant at 5 percent level. Further analysis of the result of table 4.3 revealed that, fluctuations in the RGDP that results from each of the independent or the totality of the regressors are corrected at the speed of 12 percent. Put differently, the speed of adjustment of the model is 12 percent. This means that temporal distortion in the model emanating from the independent variables will be adjusted and return to equilibrium in the long-run at the speed of $12 \%$.

\subsection{Conclusion}

Informed by the empirical findings of the study, we can debt overhang measured using indices such as public domestic bank debt outstanding, public domestic non-bank debt outstanding, public foreign multilateral debt outstanding, and public foreign informal debt outstanding stimulates gross domestic product in Nigeria. This discovery is in sync with the discovery or findings of Kasidi \& Said (2013) and Onuorah and Nkwazema (2014) which discovered that debt overhang relates positive and significantly to output stimulation.

Conclusively, external debt is a veritable tool that could be utilized in accelerating yearly increase in goods and services produced in Nigeria.

\subsection{Recommendations}

Guided by the empirical findings of the study, the following recommendations are advanced:

i. The study recommends that the Federal government should keep in check the current level of deficits within the prevailing level.

ii. Federal government of Nigeria should reduce the level of deficits as it has potentials of crowding-out private sector investment in Nigeria.

iii. The Federal government of Nigeria should ensure that external funds borrowed are channelled to projects to which they are priori designated for as PFBD impact on real GDP was found to be insignificant.

\section{References}

Adamu, I. M., \& Rasiah, R. (2016). External debt and growth dynamics in Nigeria. African Development Review, 28(3), 291-303.

Adeoye T. (2006). Fiscal policy and growth of the Nigerian economy, Nigerian Institute of Social and Economic Research Monograph Series, no. 3.

Adesuyi, O.O \& Falowo, E (2013), Impact of Fiscal Deficit financing on MacroOutput Stimulation in Nigeria, International Journal of Research in Management, 3(5), 143-172.

Bamidele, T. B., \& Joseph, A. I. (2013). Financial crisis and external debt management in Nigeria. International Journal of Business and Behavioral Sciences, 3(4), 16-28.

Barro, R. (1989). The Ricardian Approach to Budget Deficits. Journal of Economic Perspective, 3(1), 137-141.

Boboye, A. L. \& Ojo, O. M. (2012). Effect of External Debt on Economic Growth and Development of Nigeria, International Journal of Business and Social Science, 3(12), 297 - 304.

Cecchetti, S., Mohanty, M. S. \& Zampolli, F. (2011). The Real Effects of Debt, Bank for International Settlement Working Papers (352).

Dickey, D. A., \& Fuller, W. A. (1979). Distribution of the estimators for autoregressive time series with a unit root. Journal of the American statistical association, 74(366a), 427-431. 
Edame, G.E \& Okoi, O.B (2015), Fiscal Deficits and Output Stimulation in Nigeria: A Chow Test Approach, International Journal of Economics and Financial Issues, 5(3), 748-752.

Ezeabasili, V.N \& Nwakoby, C.N. (2013). Fiscal Deficits and Private Investment: Econometric Evidence from Nigeria, International journal of Innovative Research in Management, 2 (3), 01-18.

Fasoranti, M.M., Amasoma, D. (2013), Analysis of the relationship between fiscal deficits and external sector performance in Nigeria. Journal of Economics and Sustainable Development, 4(11), 80-87.

Kasidi, F., \& Said, A. M. (2013). Impact of external debt on economic growth: A case study of Tanzania. Advances in Management and Applied economics, 3(4), 59.

Krugman, R. (1988). Financing versus forgiving a debt overhang. Journal of development Economics. 5(1), 253 268.

Malik, S., Hayat, M. K., \& Hayat, M. U. (2010). External debt and economic growth: Empirical evidence from Pakistan. International Research Journal of Finance and Economics, 44(44), 1450-2887.

Mbah, S. A., \& Umunna, G. \&Agu O. C.(2016). Impact of external debt on economic growth in Nigeria: An ARDL Bound Testing Approach. In Proceedings of the Fifth Middle East Conference on Global Business, Economics, Finance and Banking (ME16Dubai October Conference) ISBN: 978-1-94357927-3 Dubai-UAE. 14-16 October 2016. Paper ID: DF601.

Mohanty, R.K. (2012), Fiscal deficit-Output Stimulation nexus in India: A cointegration analysis. New Delhi: Centre for Economic Studies \& Planning, School of Social Sciences Jawaharlal Nehru University.

Nyong, M. O. (2005). International Economics: theory, policy and application. Calabar, Wusen publishers.

Ogege, S., \& Ekpudu, J. E. (2010). The effects of debt burden on the Nigerian economy. Journal of Research in National Development, 8(2).

Ojong, C.M., Owui, H. (2013), Effect of budget deficit financing on economic development of the Nigerian economy: 1980-2008. European Journal of Business and Management, 5(3), 61-84

Omotosho, B. S., Bawa, S., \& Doguwa, S. I. (2016). Determining the optimal public debt threshold for Nigeria. CBN Journal of Applied Statistics, 7(2), 1-25.

Onuorah, A. C. C., \& Nkwazema, O. G. (2014). Deficit financing and the growth of Nigeria Economy. International Journal of Management Sciences and Business Research, 3(2), 1.

Osuka, B.O \& Chioma, A.J (2014). The Impact of Budget Deficits On Macro-Economic Variables In The Nigerian Economy (1981 - 2012), International Journal for Innovation Education and Research, 2(11), 164-183.

Paiko,I.I (2012), Debt overhang And Its Implication On Private Sector Investment: The Nigerian Experience, Arabian Journal of Business and Management Review, 1(10), 45-62.

Philips, A. O. (1997). Nigerian Fiscal Policy (1960 -1997). Nigerian Institute of Social Economic Research (NISER), Monograph Series No. 17, Ibadan.

Ritschl, A., \& Sarferaz, S. (2014). Currency versus banking in the financial crisis of 1931. International Economic Review, 55(2), 349-373.

Sichula, M. (2012). Debt Overhang and Economic Growth in HIPC Countries. The Case of Southern African Development Community (SADC), International Journal of Economics and Finance, 4(10), 82 - 92.

Siddique, R. \& Malik, A. (2001). Debt and Economic Growth in South Asia. The Pakistan Development Review, 40(4), 677-688.

Sulaiman, L. A., \& Azeez, B. A. (2012). Effect of external debt on economic growth of Nigeria. Journal of Economics and Sustainable Development, 3(8), 71-79. 
Udoka, C.O \& Ogege, S. (2012). Debt Overhang and the Crisis of Development in Nigeria Econometric Investigation, Asian Journal of Finance \& Accounting, 4(2), 231-243.

Umaru, A.D., Gatawa, A.U. (2014), Fiscal deficit and Output Stimulation in Nigeria (1970-2011): A disaggregated approach. JORIND, 12(1), 1-9.

Wright, A. \& Grenade, K. (2014). Determining Optimal Public Debt and Debt-Growth Dynamics in the Caribbean, Research in Applied Economics, 6(2), 274-301. 